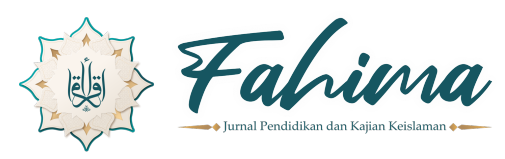

Fahima: Jurnal Pendidikan dan Kajian Keislaman

E-ISSN: 2808-4349 | P-ISSN: 2808-747X | Volume 1 No. 1 Januari 2022

\title{
PENGARUH PERHATIAN ORANG TUA DAN PEMBELAJARAN JARAK JAUH TERHADAP KESADARAN BERAKHLAK MULIA PESERTA DIDIK
}

\author{
Muhammad Qowiyul Aziz'* ${ }^{*}$ A. Mufrod Teguh Mulyo² \\ ${ }^{1}$ MA Raudlatul Ma'arif Sendanglo, Boyolali, Indonesia. \\ ${ }^{1}$ Universitas Nahdlatul Ulama Surakarta, Indonesia. \\ *Surel Penulis Koresponden: azizahmad.solo@gmail.com
}

\begin{tabular}{|l|l|l|l|}
\hline \multicolumn{4}{|c|}{ Riwayat Artikel } \\
\hline Dikirim: 5/11/2021 & Ditinjau: 18/11/2021 & Diperbaiki: 2/1/2022 & Diterima: 3/1/2022 \\
\hline
\end{tabular}

\begin{abstract}
Abstrak
Perbatian orang tua merupakan salah satu faktor penting dalam mendukung tumbuh dan perkembangan anak terutama dalam dunia pendidikan. Penelitian ini bertujuan untuk. menganalisis pengaruh perhatian orang tua dan pembelajaran jarak jauh terhadap kesadaran berakblak mulia peserta didik kelas VIII MTsN Boyolali Tabun Pelajaran 2020/2021.

Penelitian kuantitatif pada bulan Mei - Juli 2021. Populasi berjumlah 211 orang dan sampel menurut tabel Krejcie dan Morgan berjumlah 136 orang atau 64,45\%. Teknik sampling menggunakan stratified simple random sampling. Pengumpulan data menggunakan angket, wawancara, dan observasi. Analisis data menggunakan analisis deskriptif, korelasi Product Moment, regresi, uji t, uji $\mathrm{F}$, dan uji $\mathrm{R} 2$.

Hasil penelitian bahwa pengaruh perhatian orang tua terhadap kesadaran berakblak mulia peserta didik dengan nilai thitung 7,941 > tabel 1,97. Pengaruh pembelajaran jarak jauh terhadap kesadaran berakblak mulia dengan nilai thitung 6,898 $>t_{\text {tabel }}$ 1,97. Pengaruh perhatian orang tua dan pembelajaran jarak jaub terhadap kesadaran berakblak mulia peserta didik kelas VIII MTsN 10 Boyolali Tabun Pelajaran 2020/2021 dilihat hasil Fhitung sebesar 50,980 dan nilai signifikansi sebesar 0,000 sehingga p-value $(0,000)<0,05$. Kontribusi perhatian orang tua dan pembelajaran jarak jauh terhadap kesadaran berakblak mulia sebesar 43,4\% sedangkan sisanya sebesar 56,6\% yang menunjukkan besaran pengarub dari variabel lain di luar model penelitian ini.
\end{abstract}

Kata Kunci: Perhatian orang tua, pembelajaran jarak jauh, berakhlak mulia

\footnotetext{
Abstract

Parental attention is one of the essential factors in supporting the growth and development of children, especially in the world of education. This study aims to analyze the effect of parental attention and distance learning on the awareness of the noble character of the VIII grade students of MTsN Boyolali academic year 2020/2021.
} 
This quantitative research was carried out in May - July 2021. The population was 211 people, and the sample, according to Krejcie and Morgan's table, was 136 people or $64.45 \%$. The sampling technique used stratified simple random sampling. Collect data using questionnaires, interviews, and observations. Data analysis used descriptive analysis, Product Moment correlation, regression, $t$-test, $F$ test, and $\mathrm{R} 2$ test.

The results showed parental attention's influence on the awareness of students' noble character with $t_{\text {count }} 7.941>t_{\text {table }}$ 1.97. The effect of distance learning on the understanding of noble character with $t_{\text {count }} 6.898>t_{\text {table }}$ 1.97. The influence of parental attention and distance learning on the awareness of the noble character of class VIII MTsN 10 Boyolali students in the 2020/2021 academic year can be seen from the $F_{\text {count }}$ of 50.980 and the significance value of 0.000 so that the p-value $(0.000)<0.05$. The contribution of parental attention and distance learning to awareness of noble character is $43.4 \%$, while the remaining $56.6 \%$ indicates the magnitude of the influence of other variables outside the research model.

Keywords: Parents' attention, distance learning, noble character

\section{A. PENDAHULUAN}

Pendidikan sebagaimana tertuang dalam Undang-undang Sistem Pendidikan Nasional (Sisdiknas) nomer 20 tahun 2003 adalah usaha sadar dan terencana untuk mewujudkan suasana belajar dan proses pembelajaran agar peserta didik secara aktif mengembangkan potensi dirinya untuk memiliki kekuatan spiritual keagamaan, pengendalian diri, kepribadian, kecerdasan, akhlak mulia, serta keterampilan yang diperlukan dirinya, masyarakat, bangsa, dan negara. Hal ini menekankan bahwa pendidikan menjadi pondasi yang amat penting dalam proses terbentuknya sumberdaya manusia dalam suatu negara untuk mengembangkan potensi yang ada dalam diri setiap peserta didik, diharapkan nantinya dapat berguna untuk keperluan diri sendiri, masyarakat maupun bangsa dan Negara.

Undang-Undang RI Nomor 20 Tahun 2003 tentang Sistem Pendidikan Nasional, akhlak mulia menjadi salah satu konten pendidikan yang tidak boleh terlupakan, sebab akhlak mulia harusnya dimiliki oleh semua manusia. Bila berkaca pada pernyataan Nabi Muhammad saw yang mengatakan bahwa beliau diutus oleh Allah dalam rangka menyempurnakan akhlak, maka dapat diambil dasar bahwa akhlak mulia ini merupakan sesuatu yang utama dan menjadi pangkal ajaran dalam risalah Nabi Muhammad saw. Oleh karena itu, akhlak merupakan ajaran Islam yang sesungguhnya menjadi inti dari semua ibadah.

Undang-Undang RI No. 20 Tahun 2003 Bab I Pasal 1 ayat 1, diungkapkan bahwa:

Pendidikan adalab usaha sadar dan terencana untuk mewujudkan suasana belajar dan proses pembelajaran agar peserta didik secara aktif mengembangkan dirinya untuk memiliki kekuatan spiritual keagamaan, pengendalian diri, 
kepribadian, kecerdasan, akblak muia, serta ketrampilan yang diperlukan dirinya, masyarakat bangsa dan Negara (Departemen Agama RI, 2007).

Selanjutnya dalam Bab II Pasal 3 diungkapkan pula bahwa:

Pendidikan nasional berfungsi mengembangkan kemampuan dan membentuk watak serta peradaban bangsa yang bermartabat dalam rangka mencerdaskan kehidupan bangsa, bertujuan untuk berkembangnya potensi peserta didik agar menjadi manusia yang beriman dan bertaqwa kepada Tuhan Yang Maha Esa, berakblak. mulia, sehat, berilmu, cakap, kreatif, dan mandiri dan menjadi warga Negara yang demokratis serta bertanggung jawab (Departemen Agama RI, 2007).

Undang-undang RI No 20 tentang Sistem Pendidikan Nasional tersebut sangat jelas mengatakan bahwa pendidikan itu tidak hanya mengembangkan ranah kognitif (kecerdasan, berilmu, cakap) semata tetapi lebih dari itu, dituntut untuk mengembangkan ranah afektif (spiritual keagamaan, pengendalian diri, kepribadian, dan akhlak mulia) dan ranah psikomorik (kreatif, mandiri, ketrampilan). Di sini diterangkan bahwa pendidikan itu merupakan rangkaian kegiatan pendewasaan baik dari sisi pengetahuan, sikap atau perilaku, dan ketrampilan. Apabila hari ini banyak orang yang memiliki akhlak yang buruk, ditandai dengan lahirnya perilakuperilaku yang bertentangan dengan moralitas bangsa dan norma-norma agama seperti korupsi, narkoba, pemerkosaan, dan sebagainya, itu karena dulu mereka hanya dicerdaskan otaknya saja, mereka kering dengan nilai-nilai spiritual keagamaan. Sekarang mesti ada keberanian untuk berbenah diri dengan memperbaiki generasi muda sejak dini, sebab mereka adalah para penerus perjuangan bangsa dan agama.

Islam menempatkan akhlak pada posisi yang sangat penting karena akhlak adalah sikap yang melahirkan perbuatan dan tingkah laku mungkin baik atau mungkin buruk. Baik buruknya akhlak seseorang menjadi salah satu syarat sempurna atau tidaknya keimanannya. Menurut Ali bahwa seseorang dikatakan beriman apabila akhlaknya sudah baik, antara ucapan dan perkataannya telah sesuai dengan ajaran agama. Akhlak umat Islam merupakan masalah yang ingin diperbaiki oleh Islam hal ini dapat dilihat dari berbagai sunnah dalam perkataan Rasulullah diantaranya "sesungguhnya aku diutus untuk menyempurnakan akhlak manusia" (Ali, 2008).

Akhlak mulia diwujudkan tidak hanya diserahkan kepada sekolah saja. Tetapi perlu juga kerjasama antar warga sekolah, terutama orang tua. Orang tua adalah pembimbing belajar siswa di rumah. Penanggungjawab utama siswa adalah orang tuanya. Karena keterbatasan kemampuan orang tua melimpahkan sebagian tanggung jawabnya kepada sekolah, tetapi mereka lepas sama sekali dari tanggung jawab tersebut. Orang tua dituntut 
memberikan bimbingan belajar dirumah. Agar ada keserasian antara bimbingan yang diberikan oleh guru di sekolah dengan orang tua di rumah maka diperlukan kerjasama antara kedua pihak. Dalam belajar anak membutuhkan bimbingan dari orang tua, apalagi ketika anak menemukan kesulitan dalam suatu mata pelajaran. Namun ketika orang tua tidak mampu memberi solusi maka orang tua berusaha membantu anak dengan mencarikan orang lain untuk memberi solusi terhadap kesulitan anak. Dengan demikian anak merasa termotivasi untuk terus belajar.

Bimbingan kepada anak sebagai salah satu bentuk dari perhatian orang tua. Bimbingan belajar terhadap anak berarti bantuan kepada anak dalam menghadapi segala masalah dalam belajarnya. Anak sangat memerlukan bimbingan dari orang tua, terlebih lagi dalam masalah belajar. Seorang anak mudah sekali putus asa karena masih labil, untuk itu orang tua perlu memberikan bimbingan pada anak selama belajar.

Perhatian orang tua merupakan salah satu faktor penting dalam mendukung tumbuh dan perkembangan anak terutama dalam dunia pendidikan. Wujud perhatian orang tua yang menjadi tugas utama mereka adalah mendidik dan membimbing anaknya agar kelak menjadi insan yang dapat mengabdikan diri kepada Allah, kepada orang tua, agama, bangsa, dan negara. Upaya mendidik dan membimbing anak merupakan bagian yang tidak dapat terpisahkan dari serangkaian kewajiban yang harus dilaksanakan oleh orang tua. Kewajiban mendidik dan membimbing anak adalah dalam rangka memenuhi kebutuhan mental rohani anak. Dengan begitu, antara kewajiban mencari nafkah dan mendidik anak itu, satu dengan lainnya tidak dapat dipisahkan harus dilaksanakan secara seiring, sejalan, serasi, dan setara agar terjadi keseimbangan dalam pertumbuhan dan perkembangan anak.

Perhatian orang tua dapat dinyatakan sebagai perhatian yang diberikan dari ayah dan ibu. Dalam menjalankan tugas mendidik, orang tua membimbing anaknya. Anak sebagai manusia yang belum sempurna perkembangannya dipengaruhi dan diarahkan orang tua untuk mencapai kedewasaan. Kedewasaan dalam arti keseluruhan, yakni dewasa secara biologis (badaniyah) dan dewasa secara rohani (Ma'unah, 2009).

Pendidikan anak menjadi tanggung jawab keluarga (orang tua), Sebagaimana firman Allah SWT dalam QS.Al. Tahrim ayat 6:

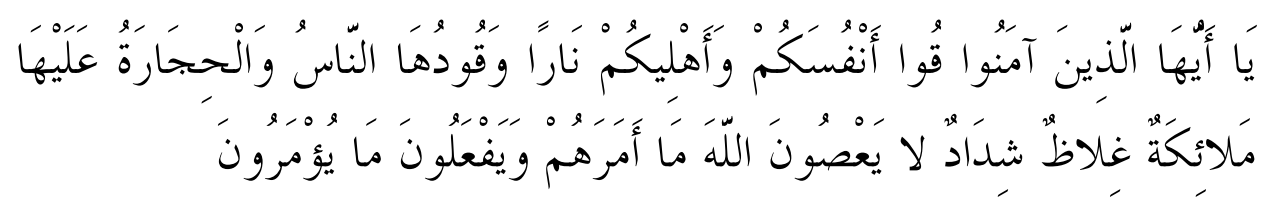

Artinya: Hai orang-orang yang beriman, peliharalah dirimu dan keluargamu dari api neraka yang bahan bakarnya adalah manusia dan batu; penjaganya 
malaikat-malaikat yang kasar, yang keras, yang tidak mendurbakai Allah terbadap apa yang diperintahkan-Nya kepada mereka dan selalu mengerjakan apa yang diperintahkan (Direktorat Urusan Agama Islam, 2012).

Ayat tersebut secara tersurat menjelaskan bahwa kewajiban dan tanggung jawab keluarga khususnya orang tua adalah menjamin masa depan anaknya baik di dunia maupun di akhirat. Jadi dapat disimpulkan bahwa perhatian orang tua adalah bentuk kepedulian orang tua kepada anak khususnya dalam kegiatan belajar anak. Perhatian ini dapat ditunjukkan dalam bentuk pemberian bimbingan, memperhatikan dan memenuhi kebutuhan alatalat penunjang pembelajaran, memberikan pengawasan, memberikan penghargaan dan hukuman, dan lain sebagainya supaya siswa mencapai prestasi belajar yang memuaskan.

Orang tua menghendaki agar anaknya tumbuh dan berkembang menjadi anak yang memiliki kepribadian yang luhur, cerdas, sehat jasmani dan rohani, terampil dan berakhlak mulia, serta segala sesuatu yang bersifat positif yang ada dalam diri anak. Setiap orang tua mempunyai cita-cita untuk mendidik dan membimbing anak-anaknya. Menjadi anak yang beriman dan bertaqwa kepada Allah Yang Maha Esa, berakhlak mulia, berbakti terhadap orang tua, berguna bagi dirinya, masyarakat, nusa, bangsa, negara, juga bagi agama, serta menjadi anak yang cerdas yang memiliki kepribadian yang utuh.

Pendidikan dalam keluarga bersifat secara ilmiah, tidak bersentuhan sama sekali dengan perencanaan yang sistematis, apalagi berlandasan dengan kurikulum yang terprogram secara hierarki. Hal ini karena keluarga sebagai madrasatul ula, yaitu sekolah pertama, dalam sejarah kehidupan anak. Orang tua (ayah atau ibu) adalah guru yang utama dan pertama bagi anak dalam pendidikan keluarga.

Tingkat kemampuan berfikir yang rendah menjadi penyebab ketidak mampuan di antara orang tua melakukan analisis, sintetis, dan evaluasi terhadap kesalahan metodelogis yang telah dilakukan dalam mendidik anakanaknya. Menurut Syaiful bahwa kesalahan orang tua dalam mendidik anak sering tampak disebabkan oleh kelemahan metodelogis dalam mendidik anak. Kebanyakan orang tua memiliki kemampuan mendidik secara metodelogistradisionalis, yaitu suatu cara yang terwariskan secara turun temurun (Djamarah, 2014).

Orang tua merupakan pendidik pertama dan utama yang dikenal oleh anak. Hal ini disebabkan karena kedua orang tuanyalah orang yang pertama dikenal dan diterimanya. Pendidikan bimbingan, perhatian, dan kasih sayang yang terjalin antara kedua orang tua dengan anak-anaknya merupakan basis yang ampuh bagi pertumbuhan dan perkembangan psikis serta nilai-nilai sosial dan religius pada diri anak didik. Perkembangan agama pada masa anak terjadi 
melalui pengalaman hidupnya sejak kecil dalam keluarga. Semakin banyak pengalaman yang bersifat agamis, semakin banyak unsur agama, maka sikap tindakan, kelakuan dan caranya menghadapi hidup yang sesuai dengan ajaran agama.

Pendidikan agama dan spiritual bagi anak-anak adalah termasuk bidang-bidang yang harus mendapat perhatian penuh oleh keluarga. Karena tanggung jawab orang tua terhadap pendidikan anaknya bersifat sangat mengikat. Perhatian orang tua kepada anak hendaknya diwarnai dengan kasih sayang orang tua terhadap anak, anak kepada orang tua dan perhatian yang memadai di dalam kehidupan keluarga. Peran orang tua sebagai pengajar utama dan pertama bagi anak sangat besar.

Orang tua yang memberikan perhatian cukup baik terhadap pendidikan anak mampu memberikan pengaruh yang positif terhadap kesadaran berakhlak mulia. Perhatian orang tua merupakan hal yang sangat dibutuhkan oleh seorang anak dalam membantu tumbuh kembangnya. Setiap orang tua pasti menginginkan anaknya tumbuh menjadi manusia yang pintar, cerdas, dan bisa menata kehidupan lebih baik dari orang tuanya saat ini. Hal tersebut dapat tercapai apabila anak berhasil di dalam proses pembelajarannya. Salah satu yang menentukan dan dapat membantu keberhasilan belajar anak adalah perhatian orang tua. Oleh karena itu orang tua harus menyadari pentingnya perhatian yang di berikan orang tua kepada anaknya terhadap keberhasilannya dalam belajar.

Peningkatan sumber daya manusia merupakan tuntutan yang harus dipenuhi oleh instansi pendidikan. Berbagai macam cara atau metode-metode pembelajaran telah diupayakan, agar siswa dapat menerima materi pelajaran dengan baik. Dalam era global seperti sekarang ini, manusia harus berhubungan dengan teknologi khususnya teknologi informasi. Hal ini disebabkan karena teknologi telah mempengaruhi kehidupan sehari-hari. Oleh karena itu, sebaiknya manusia tidak gagap teknologi. Banyak hasil penelitian menunjukkan bahwa siapa yang terlambat menguasai informasi, maka terlambat pulalah memperoleh kesempatan-kesempatan untuk maju (Prawiradilaga \& Siregar, 2004).

Kehidupan manusia di era global ini selalu berhubungan dengan teknologi. Teknologi pada hakikatnya adalah alat untuk mendapatkan nilai tambah menghasilkan produk yang bermanfaat. Teknologi sekarang ini berkembang dengan pesat. Teknologi telah mempengaruhi manusia dalam kehidupannya sehari-hari, sehingga jika 'gagap teknologi' dapat terlambat menguasai informasi, dan tertinggal pula untuk memperoleh kesempatan untuk maju. Informasi memiliki peran penting dan nyata, apalagi mayarakat sekarang sedang menuju pada era masyarakat informasi (information society) atau 
masyarakat ilmu pengetahuan (knowledge society) (Munir, 2009). Tahun 1980-an, dunia pendidikan mulai diperkenalkan suatu wawasan pembelajaran jarak jauh secara langsung menggunakan speaker dimana hanya ada seorang guru yang harus mengajar beberapa kelas secara langsung, ini adalah awal mula dari pembelajaran jarak jauh (Holmes, 2006).

Orang tua siswa yang terbiasa menggunakan teknologi mungkin tidak menjadi masalah, tetapi bagi orang tua siswa yang awam dalam penggunaan teknologi menjadi tantangan tersendiri dalam membimbing anaknya pada situasi ini. Hal ini tentu bukan hal yang mudah bagi semua elemen Pendidikan terutama orang tua menghadapi transisi dalam sistem pembelajaran ini. Sebelum adanya situasi ini, tidak banyak waktu orang tua dalam membimbing anaknya, bahkan sampai orang tua hanya sekedar sebagai pemenuh materi saja. Namun hari ini situasinya berubah, orang tua menjadi lebih banyak waktu dalam membimbing anaknya dan terjalin kedekatan emosional lebih dari sebelumnya. Peran serta orang tua siswa dalam sistem belajar di rumah ini tidak bisa dipungkiri. Jika dokter sebagai garda terdepan dalam menangani Covid-19, maka orang tua baik ayah maupun ibu adalah garda terdepan yang mengawal anak-anaknya tetap belajar di rumah masing-masing.

MTsN 10 Boyolali mulai tahun Pelajaran 2020/2021 menerapkan pembelajaran jarak jauh. Hal ini sesuai dengan Surat Edaran (SE) yang dikeluarkan Menteri Pendidikan dan Kebudayaan Republik Indonesia pada 24 Maret 2020 tentang pelaksanaan kebijakan pendidikan dalam masa darurat penyebaran covid, dalam Surat Edaran tersebut dijelaskan bahwa proses belajar dilaksanakan di rumah melalui pembelajaran daring/jarak jauh dilaksanakan untuk memberikan pengalaman belajar yang bermakna bagi siswa.

Proses pembelajaran terdapat interaksi antara guru dan siswa dan terdapat timbal balik antara guru dan siswa dalam situasi kelas yang kondusif dan edukatif. Nanun pada kenyataannya pendidikan di Indonesia selalu berkembang dengan adanya perubahan dan terdapatnya metode-metode baru dalam pembelajaran. Selain itu karena adanya kendala yang disebabkan pandemi Covid-19, sehingga pembelajaran dilakukan pembelajaran jarak jauh dengan berbagai aplikasi yang memungkinkan guru dan murid tidak perlu tatap muka secara langsung dalam melaksanakan proses pembelajaran. Di antaranya tidak semua anak sama dalam hal kepemilikan fasilitas seperti HP; banyak di antara para siswa yang hanya memiliki HP, sebutlah HP biasa. Selain itu jika pun ada HP, keterbatasan kuota dan jaringan yang kurang mendukung juga menjadi kendala.

Pembelajaran jarak jauh (PJJ) sesuai dengan UU No. 20 Tahun 2003 Pasal 1 ialah pendidikan yang peserta didiknya terpisah dari pendidik dan 
pembelajarannya menggunakan berbagai sumber belajar melalui teknologi komunikasi, informasi, dan media lain. Namun dalam proses kegiatan pembelajaran guru mengalami kendala yang terjadi dilapangan saat proses kegiatan pembelajaran. Tidak semua siswa dapat memahami materi yang diberikan lewat tugas tugas, karena ada beberapa yang tidak mengerjakan ataupun tidak awasi oleh orang tua sehingga timbulah permasalahan dalam pembelajaran jarak jauh. Sedangkan pembelajaran jarak jauh ini menekankan pada pembelajaran secara mandiri, dimana peserta didik diberikan materi belajar, tanpa adanya pengawasan langsung yang diberikan oleh pengajar atau tutor yang hadir ditempat.

Pembelajaran jarak jauh dirancang untuk melayani pembelajar dalam yang besar dengan latar belakang pendidikan, usia, dan tempat tinggal yang beragam. Dengan demikian pembelajaran jarak jauh untuk mengatasi batasan jarak, tempat serta waktu dalam melaksanakan proses pembelajaran. Oleh karena itu, pembelajaran jarak jauh memiliki karakteristik atau ciri yang khas berbeda dengan sistem pendidikan yang diselenggarakan secara konvensional secara tatap muka. Karakteristik itu adalah terpisahnnya secara fisik antara aktivitas pengajar dan pembelajar dan tidak ada tatap muka secara langsung, sehingga terjadi keterbatasan proses pembelajaran.

Latar belakang di atas maka penelitian ini berusaha untuk mengungkap keterkaitan antara pembelajaran jarak jauh, perhatian orang tua, dan akhlak mulia bagi peserta didik. Dalam pemberian bimbingan, Orang tua memberikan perhatian dan motivasi kepada anak. Perhatian dari orang tua sangat membantu anak dalam peningkatan belajar di rumah maupun di sekolah, juga bermanfaat bagi perkembangan psikologis anak. Perhatian orang tua dapat berwujud tersedianya sarana dan prasarana belajar yang menjadikan anak lebih bersemangat dalam menjalankan aktivitas belajarnya.

\section{B. METODE PENELITIAN}

Penelitian merupakan penelitian lapangan. Dalam penelitian lapangan berbeda dengan penelitian pustaka. Penelitian Pustaka, menggunakan berbagai bahan pustaka (seperti buku, jurnal, dsb) sebagai sumber primer nya (sumber utama). Sedangkan dalam penelitian lapangan, sumber primernya dihasilkan dari berbagai metode yang diaplikasikan di lapangan, seperti wawancara, observasi, survey, dan lain sebagainya. Penelitian ini menggunakan metode penelitian kuantitatif bersifat korelasional yang umum dipergunakan oleh peneliti sosial dalam menyusun penelitian ilmiah dengan generalisasi penelitian yang lintas batas dan tidak cenderung pada etnik budaya sosial suatu masyarakat tertentu. Pendekatan penelitian digunakan penelitian kuantitatif merupakan penyederhanaan kompleksitas gejala dengan mereduksi kedalam 
ukuran yang yang ditangani dan diukur (Purwanto, 2009). Penelitian ini menggunakan survei kepada beberapa siswa, sebagai sampel, dari sejumlah siswa kelas VIII. Dari ratusan pelajar yang mengikuti belajar mengajar di MTsN 10 Boyolali diambil sebagian darinya untuk mewakili populasi.

Populasi adalah wilayah generalisasi yang terdiri atas obyek atau subyek yang mempunyai kualitas dan karakteristik tertentu yang ditetapkan oleh peneliti untuk dipelajari dan kemudian ditarik kesimpulannya (Sugiyono, 2015). Dalam penelitian ini yang menjadi populasi adalah seluruh peserta didik kelas VIII MTsN 10 Boyolali tahun ajaran 2020/ 2021 sebanyak 211.

Sampel penelitian ini berdasarkan kriteria pengambilan sampel menurut tabel Krejcie dan Morgan berjumlah 136 orang atau 64,45\% dari total populasi 211 orang. Sugiyono menjelaskan bahwa sampling merupakan teknik pengambilan sampel. Teknik sampling dalam penelitian ini menggunakan stratified simple random sampling, yaitu pengambilan sampel anggota populasi dilakukan secara acak tanpa memperhatikan strata yang ada dalam populasi itu.

Untuk lebih jelas hubungan antara variabel dapat dilihat pada gambar dibawah ini:

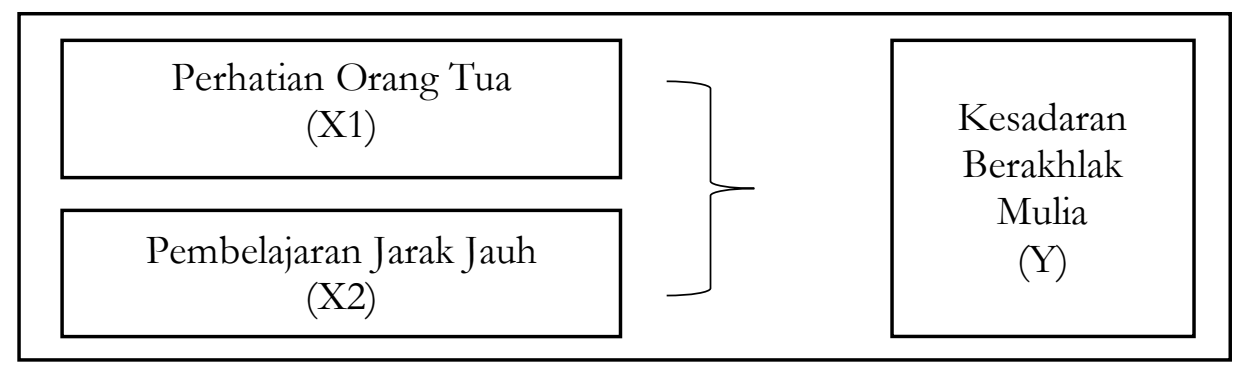

Gambar 1. Kerangka Berfikir

Metode pengumpulan data adalah cara yang digunakan dalam penelitian dengan tujuan untuk mendapatkan data-data yang dibutuhkan. Metode yang digunakan dalam penelitian ini meliputi; wawancara, observasi, dokumentasi, dan kuesioner.

Tabel 1. Kisi-kisi Kuesioner Penelitian

\begin{tabular}{|l|l|c|c|}
\hline \multirow{1}{*}{ Variabel } & \multicolumn{1}{|c|}{ Indikator } & No. Soal & $\begin{array}{c}\text { Jml } \\
\text { Soal }\end{array}$ \\
\hline Perhatian \\
Orang Tua & Memberikan bimbingan & $1,2,3,4$ & 4 \\
\cline { 2 - 4 } & Pengawasan terhadap belajar & $5,6,7,8$ & 4 \\
\cline { 2 - 4 } & $\begin{array}{l}\text { Pemberian penghargaan dan } \\
\text { hukuman }\end{array}$ & $9,10,11,12$ & 4 \\
\cline { 2 - 4 } & Pemenuhan kebutuhan belajar & $13,14,15$ & 3 \\
\cline { 2 - 4 } & Penciptaan suasana belajar yang & $16,17,18$, & 5 \\
\hline
\end{tabular}


Fahima: Jurnal Pendidikan dan Kajian Keislaman

E-ISSN: 2808-4349 | P-ISSN: 2808-747X | Volume 1 No. 1 Januari 2022

\begin{tabular}{|c|c|c|c|}
\hline & nyaman dan tentram & 19,20 & \\
\hline & Memperhatikan kesehatan anak & $\begin{array}{c}21,22,23, \\
24,25\end{array}$ & 5 \\
\hline & \multicolumn{2}{|l|}{ Jumlah } & 25 \\
\hline \multirow{9}{*}{$\begin{array}{l}\text { Pembelajaran } \\
\text { Jarak Jauh }\end{array}$} & Tujuan yang jelas & 1 & 1 \\
\hline & Relevan dengan kebutuhan & 2 & 1 \\
\hline & Mutu Pendidikan & 3 & 1 \\
\hline & Efisien dan efektivitas program & 4,5 & 2 \\
\hline & Pemerataan dan perluasan & 6,7 & 2 \\
\hline & kesempatan belajar & 8 & 1 \\
\hline & Kemandirian & 9 & 1 \\
\hline & Keterpaduan & 10 & 1 \\
\hline & \multicolumn{2}{|l|}{ Jumlah } & 10 \\
\hline \multirow{4}{*}{$\begin{array}{l}\text { Kesadaran } \\
\text { berakhlak } \\
\text { mulia }\end{array}$} & akhlak terhadap Allah & $\begin{array}{c}1,4,7,10,13 \\
16,19\end{array}$ & 7 \\
\hline & akhlak terhadap sesama manusia & $2,5,8,11,14,17,20$ & 7 \\
\hline & akhlak terhadap lingkungan & $3,6,9,12,15,18,21$ & 7 \\
\hline & \multicolumn{2}{|l|}{ Jumlah } & 21 \\
\hline
\end{tabular}

Data yang dikumpulkan melalaui metode pengumpulan data yang digunakan mempunyai arti apabila diolah dan dianalisis. Dari awal analisa tersebut, maka dapat dinterpretasikan, dan selanjutnya dapat dirumuskan kesimpulan akhir dari suatu penelitian. Analisis yang digunakan dalam penelitian ini adalah analisis deskriptif dan analisis statistik.

\section{HASIL DAN PEMBAHASAN}

\section{Analisis Pengaruh Perhatian Orang Tua terhadap Kesadaran Berakhlak Mulia Peserta Didik Kelas VIII MTsN 10 Boyolali Tahun Pelajaran 2020/2021}

Analisis pengaruh perhatian orang tua terhadap kesadaran berakhlak mulia pada peserta didik kelas VIII MTsN 10 Boyolali tahun pelajaran 2020/2021 diperoleh hasil sebagai berikut:

Tabel 2. Uji Linieritas Pengaruh Perhatian Orang Tua terhadap Kesadaran Berakhlak

Mulia Peserta Didik Kelas VIII MTsN 10 Boyolali Tahun Pelajaran 2020/2021

\begin{tabular}{|l|l|r|r|r|r|r|}
\hline \multicolumn{2}{|c|}{ Model } & $\begin{array}{c}\text { Sum of } \\
\text { Squares }\end{array}$ & df & Mean Square & F & Sig. \\
\hline \multirow{2}{*}{1} & Regression & 2712.065 & 1 & 2712.065 & 63.062 & $.000^{\mathrm{b}}$ \\
\cline { 2 - 7 } & Residual & 5762.810 & 134 & 43.006 & & \\
\cline { 2 - 6 } & Total & 8474.875 & 135 & & & \\
\hline \multicolumn{2}{|l}{ a. Dependent Variable: Kesadaran Akhlak Mulia (Y) } \\
\multicolumn{2}{l}{ b. Predictors: (Constant), Perhatian orang tua (X1) } \\
\hline
\end{tabular}


Hasil tabel di atas diketahui $F_{\text {hitung }} 63.062$ dengan $F_{\text {tabel }}$ untuk df 1 pada taraf signifikansi 5\% $=3,98$. Di karenakan $F_{\text {hitung }}<F_{\text {tabel }}$ atau $63,062<3,98$ berarti pengaruh perhatian orang tua terhadap kesadaran berakhlak mulia peserta didik kelas VIII MTsN 10 Boyolali Tahun Pelajaran 2020/2021 berpola linier. Selanjutnya dilakukan uji keberartian persamaan regresinya. Hasil dari analisis regresi sederhana antara pasangan data perhatian orang tua $\left(\mathrm{X}_{1}\right)$ dan kesadaran berakhlak mulia $(\mathrm{Y})$ dapat dilihat pada tabel regresi berikut:

Tabel 3. Keberartian Regresi Pengaruh antara perhatian orang tua $\left(X_{1}\right)$ terhadap kesadaran berakhlak mulia $(\mathrm{Y})$

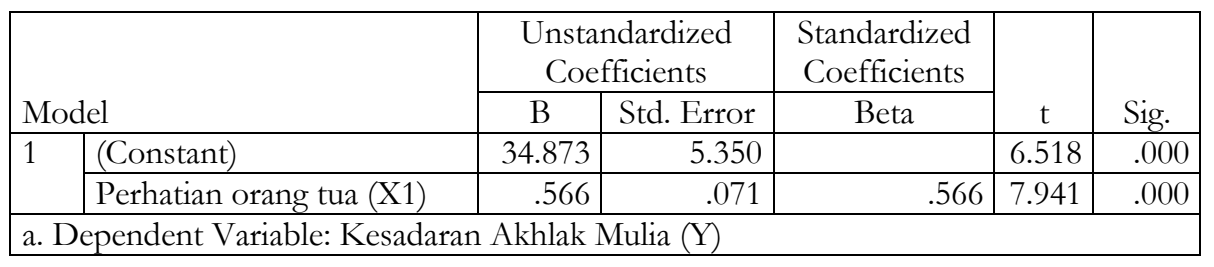

Uji keberartian regresinya dilakukan uji t, adapun kaidah keputusan untuk uji $\mathrm{t}$ adalah jika nilai $t_{\text {hitung }}>t_{\text {tabel }}$ maka Ho diterima dan $\mathrm{Ha}$ ditolah artinya tidak signifikan. Dengan menggunakan program SPSS 23 diperoleh nilai $t_{\text {hitung }} 7,941$ untuk responden sebanyak 136 . Untuk memperoleh nilai $t_{\text {tabel }}$ dengan taraf signifikansi 0,05 digunakan rumus $\mathrm{N}$ - $\mathrm{K}\left(\mathrm{N}=\right.$ jumlah sampel, $\mathrm{K}=$ jumlah variabel) sehinggat $t_{\text {tabel }}$ dari $136-1$ $=136$ adalah 1,97. Oleh karenanya nilai $t_{\text {hitung }} 7,941>t_{\text {tabel }} 1,97$, maka Ho ditolak sehingga dapat disimpulkan terdapat pengaruh yang berarti atau signifikan antara perhatian orang tua $\left(\mathrm{X}_{1}\right)$ terhadap kesadaran berakhlak mulia (Y).

Proses pendidikan manusia, terutama berkaitan dengan nilai-nilai Islami (akhlak karimah atau akhlak mulia) merupakan hal pertama dan utama dalam agama. Untuk menjadikan anak yang berakhlak mulia tentu tidaklah cukup memberikan pengetahuan saja, akan tetapi yang sangat penting adalah melalui pembinaan yang dilakukan secara berangsur-angsur melalui latihan, sehingga tertanam dalam jiwa anak dan menjadi kebiasaan berakhlak yang baik dalam kehidupan sehari-hari. Akhlak merupakan kelakuan yang timbul dari hasil perpaduan antara hati nurani, pikiran, perasaan dan pembiasaan yang menyatu dan membentuk suatu kesatuan akhlak yang dihayati dalam kehidupan sehari-hari. Akhlak yang di ajarkan dalam Al-Qur'an bertumpu kepada fitrah yang terdapat dalam diri manusia dan kemauan yang timbul dari hati.

Penanaman akhlak mulia perlu dukungan ornag tua, karena orang tua merupakan pendidik utama dan pertama bagi anak-anak mereka. Dari 
pendidikan orang tualah anak mula-mula menerima pendidikan. Kesadaran berakhlak mulia harus di dukung dengan kerjasama yang baik dan sungguhsungguh dari guru dan orang tua. Orang tua di rumah harus meningkatkan perhatiannya terhadap anak-anaknya dengan meluangkan waktu untuk memberikan bimbingan, keteladanan, dan pembiasaan yang baik.

\section{Analisis Pengaruh Pembelajaran Jarak Jauh terhadap Kesadaran Berakhlak Mulia Peserta Didik Kelas VIII MTsN 10 Boyolali Tahun Pelajaran 2020/2021}

Analisis pengaruh pembelajaran jarak jauh terhadap kesadaran berakhlak mulia pada peserta didik kelas VIII MTsN 10 Tahun Pelajaran 2020/2021 diperoleh hasil sebagai berikut:

Tabel 4. Uji Linieritas Pengaruh Pembelajaran Jarak Jauh terhadap Kesadaran Berakhlak Mulia Peserta Didik Kelas VIII MTsN 10 Boyolali Tahun Pelajaran 2020/2021

\begin{tabular}{|l|l|r|r|r|c|c|}
\hline \multicolumn{2}{|c|}{ Model } & $\begin{array}{c}\text { Sum of } \\
\text { Squares }\end{array}$ & \multicolumn{1}{c|}{ df } & Mean Square & F & Sig. \\
\hline \multirow{3}{*}{1} & Regression & 2220.609 & 1 & 2220.609 & 47.577 & $.000^{\mathrm{b}}$ \\
\cline { 2 - 6 } & Residual & 6254.266 & 134 & 46.674 & & \\
\cline { 2 - 6 } & Total & 8474.875 & 135 & & & \\
\hline
\end{tabular}

Hasil tabel di atas diketahui $F_{\text {hitung }} 47.577$ dengan $F_{\text {tabel }}$ untuk df 1 pada taraf signifikansi 5\% $=3,98$. Di karenakan $F_{\text {hitung }}<F_{\text {tabel }}$ atau 47,577<3,98 berarti pengaruh pembelajaran jarak jauh terhadap kesadaran berakhlak mulia peserta didik kelas VIII MTsN 10 Boyolali Tahun Pelajaran 2020/2021 berpola linier. Selanjutnya dilakukan uji keberartian persamaan regresinya. Hasil dari analisis regresi sederhana antara pasangan data pembelajaran jarak jauh $\left(\mathrm{X}_{2}\right)$ dan kesadaran berakhlak mulia $(\mathrm{Y})$ dapat dilihat pada tabel regresi berikut:

Tabel 5. Keberartian Regresi Pengaruh antara pembelajaran jarak jauh (X2) terhadap kesadaran berakhlak mulia $(\mathrm{Y})$

\begin{tabular}{|l|l|c|c|c|c|c|}
\hline \multicolumn{2}{|c|}{ Model } & \multicolumn{2}{|c|}{$\begin{array}{c}\text { Unstandardized } \\
\text { Coefficients }\end{array}$} & $\begin{array}{c}\text { Standardized } \\
\text { Coefficients }\end{array}$ & t & Sig. \\
\cline { 3 - 7 } & & B & $\begin{array}{c}\text { Std. } \\
\text { Error }\end{array}$ & Beta & & \\
\hline 1 & (Constant) & 43.301 & 4.939 & & 8.768 & .000 \\
\cline { 2 - 7 } & Pembelajaran Jarak Jauh (X2) & 1.028 & .149 & .512 & 6.898 & .000 \\
\hline \multicolumn{2}{|c|}{ a. Dependent Variable: Kesadaran Akhlak Mulia (Y) } \\
\hline
\end{tabular}

Uji keberartian regresinya dilakukan uji t, adapun kaidah keputusan 
untuk uji t adalah jika nilai $t_{\text {hitung }}>t_{\text {tabel }}$ maka Ho diterima dan $\mathrm{Ha}$ ditolah artinya tidak signifikan. Dengan menggunakan program SPSS 23 diperoleh nilai $t_{\text {hitung }} 6,898$ untuk responden sebanyak 136 . Untuk memperoleh nilai $t_{\text {tabel }}$ dengan taraf signifikansi 0,05 digunakan rumus $\mathrm{N}$ - $\mathrm{K}\left(\mathrm{N}=\right.$ jumlah sampel, $\mathrm{K}=$ jumlah variabel) sehinggat $t_{\text {tabel }}$ dari $136-1$ $=136$ adalah 1,97. Oleh karenanya nilai $t_{\text {hitung }} 6,898>t_{\text {tabel }} 1,97$, maka Ho ditolak sehingga dapat disimpulkan terdapat pengaruh yang berarti atau signifikan antara pembelajaran jarak jauh $\left(\mathrm{X}_{2}\right)$ terhadap kesadaran berakhlak mulia $(\mathrm{Y})$.

Beberapa manfaat pembelajaran jarak jauh antara lain memberikan pengalaman belajar yang bermakna bagi siswa, tanpa terbebani tuntutan menuntaskan seluruh capaian kurikulum kenaikan kelas maupun kelulusan. Dalam kesempatan ini, seorang anak dapat memfokuskan pada pendidikan kecakapan hidup antara lain mengenai pandemi Covid-19. Memberikan variasi aktivitas dan tugas pembelajaran belajar dari rumah antarsiswa, sesuai minat dan kondisi masing-masing, termasuk mempertimbangkan kesenjangan akses/ fasilitas belajar dari rumah. Memberikan umpan balik terhadap bukti atau produk aktivitas belajar dari rumah yang bersifat kualitatif dan berguna bagi guru, tanpa diharuskan memberi skor/nilai kualitatif.

Melalui pembelajaran jarak jauh ini orang tua atau wali murid pasti memainkan peran besar dalam membantu siswa berhasil dalam pembelajaran jarak jauh. orang tua bukan guru terlatih dan diminta untuk mengambil tugas yang menantang, sementara mereka juga berurusan dengan tugas dan tuntutan lain di rumah, untuk mendapatkan banyak bimbingan dan dorongan dari guru.

Kecanggihan teknologi komunikasi dan informasi memudahkan pola komunikasi terbangun antara guru dan orang tua. Penyampaian informasi dapat melalui media sosial seperti; Whats App, Telegram, dan sebagainya. Baik informasi tersebut bersifat umum artinya ditujukan untuk seluruh wali murid atau dapat melalui chat (percakapan) pribadi kepada wali murid yang dikehendaki. Fasilitas ini seharusnya dapat lebih mengintensifkan pola komunikasi antara keduanya. Interaksi antara orang tua dan guru melalui media sosial pada kondisi normal dapat menjadi nilai plus bagi suatu lembaga pendidikan, namun pada masa pandemi menjadi tuntutan.

\section{Analisis Pengaruh Perhatian Orang Tua dan Pembelajaran Jarak Jauh terhadap Kesadaran Berakhlak Mulia Peserta Didik Kelas VIII MTsN 10 Boyolali Tahun Pelajaran 2020/2021}

Analisis Pengaruh Perhatian Orang Tua dan Pembelajaran Jarak Jauh 
terhadap Kesadaran Berakhlak Mulia Peserta Didik Kelas VIII MTsN 10 Boyolali Tahun Pelajaran 2020/2021 diperoleh hasil sebagai berikut:

Tabel 6. Analisis Korelasi

\begin{tabular}{|c|c|c|c|c|}
\hline & & $\begin{array}{c}\text { Perhatian } \\
\text { Orang } \\
\text { Tua (X1) } \\
\end{array}$ & $\begin{array}{c}\text { Pembelajaran } \\
\text { Jarak Jauh } \\
\text { (X2) }\end{array}$ & $\begin{array}{c}\text { Kesadaran } \\
\text { Akhlak Mulia } \\
\text { (Y) }\end{array}$ \\
\hline \multirow{3}{*}{$\begin{array}{l}\text { Perhatian Orang } \\
\text { Tua (X1) }\end{array}$} & Pearson Correlation & 1 & $.345^{* *}$ & $.566^{* *}$ \\
\hline & Sig. (2-tailed) & & .000 & .000 \\
\hline & $\mathrm{N}$ & 136 & 136 & 136 \\
\hline \multirow{3}{*}{$\begin{array}{l}\text { Pembelajaran } \\
\text { Jarak Jauh (X2) }\end{array}$} & Pearson Correlation & $.345^{* *}$ & 1 & $.512^{* *}$ \\
\hline & Sig. (2-tailed) & .000 & & .000 \\
\hline & $\mathrm{N}$ & 136 & 136 & 136 \\
\hline \multirow{3}{*}{$\begin{array}{l}\text { Kesadaran } \\
\text { Akhlak Mulia } \\
\text { (Y) }\end{array}$} & Pearson Correlation & $.566^{* *}$ & $.512^{* *}$ & 1 \\
\hline & Sig. (2-tailed) & .000 & .000 & \\
\hline & $\mathrm{N}$ & 136 & 136 & 136 \\
\hline
\end{tabular}

Berdasarkan hasil korelasi di atas dapat dipaparkan bahwa:

a. Hubungan antara variabel perhatian orang tua dengan kesadaran berakhlak mulia diperoleh nilai $\mathrm{r}_{\mathrm{XY}}$ sebesar 0,566 dan p-value 0,000 . Hasil ini menunjukkan bahwa terdapat hubungan yang signifikan antara perhatian orang tua dengan kesadaran berakhlak mulia karena nilai $\mathrm{r}_{\mathrm{XY}}(0,566)$ lebih besar dari $\mathrm{r}_{\text {tabel }}(0,176)$.

b. Hubungan antara variabel pembelajaran jarak jauh dengan kesadaran berakhlak mulia diperoleh nilai $\mathrm{r}_{\mathrm{XY}}$ sebesar 0,512 dan p-value 0,000 . Hasil ini menunjukkan bahwa terdapat hubungan yang signifikan antara pembelajaran jarak jauh dengan kesadaran berakhlak mulia karena nilai $\mathbf{r}_{\mathrm{XY}}(0,512)$ lebih besar dari $\mathrm{r}_{\text {tabel }}(0,176)$.

Berdasarkan pengujian data diperoleh hasil sebagai berikut:

Tabel 7. Hasil Uji Regresi

\begin{tabular}{|c|l|c|c|c|}
\hline \multicolumn{2}{|c|}{ Model } & \multicolumn{2}{|c|}{$\begin{array}{c}\text { Unstandardized } \\
\text { Coefficients }\end{array}$} & $\begin{array}{c}\text { Standardized } \\
\text { Coefficients }\end{array}$ \\
\cline { 3 - 5 } \multicolumn{2}{|c|}{} & B & Std. Error & Beta \\
\hline \multirow{2}{*}{1} & (Constant) & 20.372 & 5.645 & \\
\cline { 2 - 5 } & Pembelajaran Jarak Jauh (X2) & .442 & .069 & .442 \\
\cline { 2 - 5 } & Pembelajaran Jarak Jauh (X2) & .722 & .140 & .360 \\
\hline
\end{tabular}

Berdasarkan tabel 7, diperoleh persamaan regresi sebagai berikut:

$\mathrm{Y}=20,372+0,442 \mathrm{X}_{1}+0,722 \mathrm{X}_{2}+\mathrm{e}$

Hasil persamaan di atas diketahui bahwa nilai konstanta bernilai positif sebesar 20,372 berarti bahwa jika tidak ada faktor independen (Perhatian Orang Tua dan pembelajaran jarak jauh) maka kesadaran berakhlak mulia 
berpotensi tetap atau tidak naik berada pada rata-rata sebesar 20,372.

Nilai koefisien regresi variabel perhatian orang tua bernilai positif sebesar 0,442 sehingga variabel perhatian orang tua memberikan kontribusi positif terhadap kesadaran berakhlak mulia sebesar 0,442 setiap adanya kenaikan perhatian orang tua sebesar satu point. Sedangkan nilai koefisien regresi variabel pembelajaran jarak jauh bernilai positif sebesar 0,722 sehingga variabel pembelajaran jarak jauh memberikan kontribusi positif terhadap kesadaran berakhlak mulia sebesar 0,722 setiap adanya kenaikan pembelajaran jarak jauh satu point.

Hasil uji $\mathrm{t}$ adalah sebagai berikut:

Tabel 8. Hasil uji $\mathrm{F}$

\begin{tabular}{|l|l|r|r|r|c|l|}
\hline \multicolumn{2}{|c|}{ Model } & Sum of Squares & \multicolumn{1}{c|}{ df } & Mean Square & F & Sig. \\
\hline \multirow{3}{*}{1} & Regression & 3677.649 & 2 & 1838.824 & 50.980 & $.000^{\mathrm{b}}$ \\
\cline { 2 - 8 } & Residual & 4797.226 & 133 & 36.069 & & \\
\cline { 2 - 8 } & Total & 8474.875 & 135 & & & \\
\hline
\end{tabular}

Hasil $\mathrm{F}_{\text {hitung }}$ sebesar 50,980 dan nilai signifikansi ( $\mathrm{p}$-value) sebesar 0,000 . Hal ini menunjukkan bahwa $\mathrm{p}$-value $(0,000)<0,05$, maka secara bersama-sama atau simultan variabel perhatian orang tua dan pembelajaran jarak jauh berpengaruh signifikan terhadap kesadaran berakhlak mulia.

Hasil uji koefisien determinasi $\left(\mathrm{R}^{2}\right)$ adalah sebagai berikut:

Tabel 9. Hasil uji koefisien determinasi $\left(\mathrm{R}^{2}\right)$

\begin{tabular}{|l|c|c|c|c|}
\hline Model & $\mathrm{R}$ & R Square & Adjusted R Square & Std. Error of the Estimate \\
\hline 1 & $.659^{\mathrm{a}}$ & .434 & .425 & 6.006 \\
\hline
\end{tabular}

Hasil perhitungan nilai R Square sebesar 0,434 (43,4\%). Hal ini berarti bahwa perhatian orang tua dan pembelajaran jarak jauh terhadap kesadaran berakhlak mulia adalah sebesar $43,4 \%$ sedangkan sisanya sebesar $56,6 \%$ (diperoleh dari 100\%-43,4\%) yang menunjukkan besaran pengaruh dari variabel lain di luar model penelitian ini.

Perhatian dan motivasi inilah yang mempunyai peran penting dalam pembentukan karakter anak. Anak yang tidak pernah mendapat teguran saat dia melakukan kesalahan, akan melakukan kesalahan terus-menerus sampai menjadi kebiasaan buruk. Akibatnya kebiasaan buruk tersebut dimaknai orang lain sebagai perilaku kenakalan. Seperti anak suka berbicara kotor dan tidak pernah mendapatkan teguran terutama dari orang tuanya, kebiasaan tersebut akan menjadi watak buruk saat dewasa. Ketika sudah menjadi watak, akan susah diubah. Inti pendidikan di keluarga adalah keteladanan pembiasaan, dan kasih sayang, terutama agar menjadi orang yang disiplin. Meskipun tugas pendampingan tergantikan oleh orang tua, guru tidak serta merta dimanjakan dengan adanya pembelajaran Daring. 
Guru dituntut dapat proaktif dan membangun pola komunikasi yang baik dengan orang tua.

Orang tua idealnya turut memantau perkembangan anak dengan memantau mereka saat belajar. Orang tua juga harus dapat menciptakan tradisi baik di lingkungan keluarga. Saat Usai Maghrib anak-anak digiring untuk belajar. Orang tua harus mempunyai sikap mawas diri untuk memberikan contoh memberdayakan kegiatan positif di waktu tersebut dengan tidak menonton TV dan menemani anak mereka belajar. Boleh saja orang tua menyela dengan kegiatan lain seperti membaca Al-Qur'an atau membaca buku atau kegiatan yang lain yang intinya anak mereka memandang orang tua mereka sibuk dengan kegiatan positif sehingga anak dapat mencontoh hal yang baik tersebut.

Mutual relationship atau Kerjasama antara guru dan orang tua disini dimaksudkan tugas guru sebagai pengajar yang terbatas hanya mampu memantau siswa pada jam sekolah dapat terbantukan oleh adanya interkoneksi antara orang tua dan guru. Sebaliknya orang tua yang pada dasarnya berkewajiban mengemban amanah untuk mendidik anaknya dapat terbantukan dari arahan orang yang berpengalaman dalam mendidik anak. Begitu sebaliknya guru yang diberi kepercayaan oleh orang tua untuk mendidiknya anaknya, tidaklah mudah tanpa adanya bantuan orang tua mengingat pendidikan adalah komprehensif tidak hanya sekedar transfer of knowledge.

Proses pendidikan atau pembentukan akhlak bertujuan untuk melahirkan manusia yang berakhlak mulia. Akhlak yang mulia akan terwujud secara kukuh dalam diri seseorang apabila setiap empat unsur utama kebatinan diri yaitu daya akal, daya marah, daya syahwat dan daya keadilan, Berjaya dibawa ke tahap yang seimbang dan adil sehingga tiap satunya boleh dengan mudah mentaati kehendak syara' dan akal. Akhlak mulia merupakan tujuan pokok pembentukan akhlak Islam ini. Akhlak seseorang akan dianggap mulia jika perbuatannya mencerminkan nilai-nilai yang terkandung dalam Al-Qur'an.

Perhatian orang tua memiliki peran yang sangat penting terhadap pendidikan dalam membentuk kepribadian dan perilaku anak karena orang tua merupakan pendidik utama dan pertama dalam keluarga. Orang tua dituntut untuk menjadi pendidik yang memberikan pengetahuan, perilaku, dan keterampilan yang memadai, suri tauladan, bertanggung jawab baik yang bersifat jasmani maupun rohani kepada anak-anaknya. Orang tua yang menyadari tanggungjawabnya terhadap pendidikan anak maka akan berusaha semaksimalnya dalam memenuhi kebutuhan belajar anak. Hal ini mampu menumbuhkan hubungan emosional antara anak dengan orang tua 
sehingga anak dalam berperilaku bisa dikontrol oleh orang tua.

\section{KESIMPULAN}

Pengaruh perhatian orangtua terhadap kesadaran berakhlak mulia peserta didik kelas VIII MTsN 10 Boyolali Tahun Pelajaran 2020/2021. Hal ini dibuktikan melalui uji keberartian regresi dengan nilai $t_{\text {hitung }}$ 7,941 > $t_{\text {tabel }}$ 1,97, maka Ho ditolak dan menerima Ha. Hal ini berarti bahwa semakin tinggi perhatian orangtua maka kesadaran berakhlak mulia bagi siswa akan semakin baik atau meningkat. Pengaruh pembelajaran jarak jauh terhadap kesadaran berakhlak mulia peserta didik kelas VIII MTsN 10 Boyolali Tahun Pelajaran 2020/2021. Hal ini dibuktikan melalui uji keberartian regresi dengan nilai $t_{\text {hitung }} 6,898>t_{\text {tabel }} 1,97$, maka Ho dan menerima Ha. Hal ini menunjukkan bahwa melalui pembelajaran jarak jauh mampu membentuk perilaku akhlak yang mulia karena adanya kedekatan emosional antara orang tua dan anak dalam menyediakan fasilitas belajar.

Pengaruh perhatian orangtua dan pembelajaran jarak jauh terhadap kesadaran berakhlak mulia peserta didik kelas VIII MTsN 10 Boyolali Tahun Pelajaran 2020/2021. Hal ini dibuktikan melalui hasil $F_{\text {hitung }}$ sebesar 50,980 dan nilai signifikansi ( $p$-value) sebesar 0,000 sehingga p-value $(0,000)<0,05$, maka secara bersama-sama atau simultan variabel perhatian orangtua dan pembelajaran jarak jauh berpengaruh signifikan terhadap kesadaran berakhlak mulia. Kontribusi perhatian orang tua dan pembelajaran jarak jauh terhadap kesadaran berakhlak mulia adalah sebesar 43,4\% sedangkan sisanya sebesar 56,6\% (diperoleh dari 100\%-43,4\%) yang menunjukkan besaran pengaruh dari variabel lain di luar model penelitian ini. 


\section{E. REFERENSI}

Ali, M. D. (2008). Pendidikan Agama Islam. PT. Raja Grafindo Persada.

Departemen Agama RI. (2007). Undang-Undang dan Peraturan Pemerintah Republik Indonesia tentang Pendidikan.

Direktorat Urusan Agama Islam. (2012). Al-Qur'an dan Terjemabnya. Depag RI.

Djamarah, S. B. (2014). Pola Asuh Orang Tua dan Komunikasi dalam Keluarga. Rineka Cipta.

Holmes, B. J. G. (2006). E-learning Concept and Practice. Sage Publication.

Ma'unah, B. (2009). Imu Pendidikan. Teras.

Munir, M. (2009). Pembelajaran Jarak Jauh Berbasis Teknologi Informasi dan Komunikasi. Alfabeta.

Prawiradilaga, D. S., \& Siregar, E. (2004). Mozaik Teknologi Pendidikan. Kencana.

Purwanto. (2009). Evaluasi Hasil Belajar. Pustaka Pelajar.

Sugiyono. (2015). Statistika Untuk Penelitian. Alfabeta. 